\title{
CLASSIFICAÇÃO FILOGENÉTICA E CARACTERIZAÇÃO GENOTÍPICA DOS ISOLADOS DE Escherichia coli PATOGÊNICA AVIÁRIA (APEC) PROVENIENTES DE GALINHAS CAIPIRAS
}

\author{
PHYLOGENETIC CLASSIFICATION AND GENOTYPICALLY \\ CHARACTERIZATION OF AVIAN PATHOGENIC Escherichia coli (APEC) \\ ISOLATED FROM BACKYARD CHICKENS \\ E. S. OLIVEIRA ${ }^{1 *}$, M. V. CARDOZO ${ }^{1}$, M. F. S. MONTASSIER ${ }^{1}$, M. M. BORZI ${ }^{1}$, \\ F. A. ÁVILA ${ }^{1}$
}

\begin{abstract}
RESUMO
A Escherichia coli patogênica aviária (APEC) é incriminada por uma variedade de doenças extraintestinais em aves, que podem causar tanto infecções localizadas, quanto generalizadas denominadas colibacilose. Os mecanismos de virulência têm sido continuamente estudados e considerados multifatoriais, assim sendo, o conhecimento da genética bacteriana capaz de gerar tais mecanismos, pode auxiliar na identificação de cepas patogênicas isoladas de aves. O presente trabalho foi delineado com o objetivo de investigar a distribuição de 17 genes de virulência em 72 cepas isoladas de galinhas caipiras pela PCR-multiplex e classificar-las nos grupos filogenéticos A, B1, B2 e D pela detecção de três marcadores de patogenicidade: $c h u \mathrm{~A}$, yjaA e um fragmento anônimo de DNA designado TSPE4.C2. Todos os isolados apresentaram os genes iss (resistência sérica), omp T (protease de membrana externa) e $h l y F$ (hemolisina F). A frequiência dos demais genes foi $66,7 \% \mathrm{cvaC}, 87,5 \%$ iroN, $88,9 \%$ iutA, 88,9\% sitA, 29,2\% tsh, 58,3\% iuc C, 83,3\% traT, 72,2\% iuc D, 81,9\% fim $\mathrm{H}, 38,9 \%$ fyu $\mathrm{A}, 77,8 \%$ irp $2,16,7 \%$ vat, $15,3 \%$ ast $\mathrm{A}$ e 1,4\% papC. A análise filogenética revelou que a maioria dos isolados pertence ao grupo filogenético B2 (39/72), seguido pelo grupo A (17/72), grupo B1 (14/72) e grupo D (2/72). Os isolados dos grupos filogenéticos B2 e D estiveram associados a um maior número de genes de virulência, apresentando uma média de 11,6 e 13,5 genes de virulência por isolado, respectivamente. Já os grupos filogenéticos A e B1 apresentaram 9,9 e 10,8 genes de virulência por isolado, respectivamente. A análise genotípica e filogenética mostrou uma heterogeneidade genética em relação ao repertório de virulência dos isolados analisados. Tais informações poderão nortear futuros trabalhos, que poderão ser desenvolvidos baseados nessas características iniciais, para a identificação de cepas virulentas e auxiliar no diagnóstico, tratamento e controle da colibacilose aviária.
\end{abstract}

PALAVRAS-CHAVE: APEC. COLIBACILOSE. GENES DE VIRULÊNCIA. GRUPOS FILOGENÉTICOS

AGRADECIMENTOS: FAPESP

ÁREA TEMÁTICA: Epidemiologia 